\title{
Possibility of exosome-based coronavirus disease 2019 vaccine (Review)
}

\author{
KWANG HO YOO $^{1 *}$, NIKITA THAPA ${ }^{2 *}$, BEOM JOON KIM ${ }^{1}$, JUNG OK LEE ${ }^{1}$, \\ YOU NA JANG ${ }^{1}$, YONG JOON CHWAE ${ }^{3}$ and JAEYOUNG KIM ${ }^{2}$ \\ ${ }^{1}$ Department of Dermatology, Chung-Ang University College of Medicine, Seoul 06973; \\ ${ }^{2}$ CK-Exogene, Inc., Seongnam, Gyeonggi-do 13201; ${ }^{3}$ Department of Microbiology, \\ Ajou University School of Medicine, Suwon, Gyeonggi-do 16499, Republic of Korea
}

Received September 24, 2021; Accepted November 16, 2021

DOI: $10.3892 / \mathrm{mmr} .2021 .12542$

\begin{abstract}
Coronavirus disease 2019 (COVID-19) is a global pandemic that can have a long-lasting impact on public health if not properly managed. Ongoing vaccine development trials involve classical molecular strategies based on inactivated or attenuated viruses, single peptides or viral vectors. However, there are multiple issues, such as the risk of reversion to virulence, inability to provide long-lasting protection and limited protective immunity. To overcome the aforementioned drawbacks of currently available COVID-19 vaccines, an alternative strategy is required to produce safe and efficacious vaccines that impart long-term immunity. Exosomes (key intercellular communicators characterized by low immunogenicity, high biocompatibility and innate cargo-loading capacity) offer a novel approach for effective COVID-19 vaccine development. An engineered exosome-based vaccine displaying the four primary structural proteins of SARS-CoV-2 (spike, membrane, nucleocapside and envelope proteins) induces humoral and cell mediated immunity and triggers long-lasting immunity. The present review investigated the prospective use of exosomes in the development of COVID-19 vaccines; moreover, exosome-based vaccines may be key to control the COVID-19 pandemic by providing enhanced protection compared with existing vaccines.
\end{abstract}

\section{Contents}

1. Introduction

2. Extracellular vesicles (EVs) and their significance

Correspondence to: Dr Jaeyoung Kim, CK-Exogene, Inc., 302 Galmachi-ro, Jungwon, Seongnam, Gyeonggi-do 13201, Republic of Korea

E-mail: caput@ naver.com

*Contributed equally

Key words: coronavirus disease 2019, exosome, vaccine, severe acute respiratory syndrome coronavirus 2 , pandemic
3. Exosome-based vaccines

4. Prospects of exosome-based COVID-19 vaccines

5. Immunological perspective of present and future vaccine development strategies

6. Safety aspect of $293 \mathrm{~T}$ cells for exosome-based vaccine production

7. Conclusion

\section{Introduction}

Coronavirus disease 2019 (COVID-19), first reported in Wuhan, China, in December 2019, caused a viral epidemic, and was declared a pandemic by the World Health Organization (WHO) in March 2020 due to a rapid surge of cases worldwide. As a pandemic, the COVID-19 outbreak may have a long-lasting impact on public health if not properly controlled. The WHO (worldometers.info/coronavirus/) confirmed 241,915,631 COVID-19 cases, including 4,921,308 deaths, worldwide up to October 19, 2021.

Severe acute respiratory syndrome coronavirus 2 (SARS-CoV-2), a positive-sense, single-stranded RNA virus, is the causative agent of COVID-19. This virus belongs to the coronavirus family, a group of enveloped viruses that primarily cause respiratory illness (1). Other viruses in this family are Middle East respiratory syndrome (MERS) and SARS viruses. SARS-CoV-2 shares $79.6 \%$ of its sequence with SARS-CoV, which caused an epidemic in 2003 (2). SARS-CoV-2 is more transmissible than SARS-CoV and MERS-CoV because it can easily spread via liquid droplets while speaking, coughing or sneezing. Infection can lead to acute respiratory syndrome, which primarily affects the lungs and can result in septic shock, pneumonia and death (3).

The SARS-CoV-2 genome contains $30 \mathrm{~kb}$ RNA, five major open reading frames and four primary structural proteins [spike (S), envelope (E), membrane (M) and nucleocapside (N)], all of which elicit immune responses (Fig. 1) (4-7). The $\mathrm{S}$ protein attaches to the host cell by binding to the angiotensin converting enzyme 2 receptor (8). Transmembrane serine protease 2 , a host cell serine protease, mediates the internalization of $\mathrm{S}$ protein, followed by its integration into the host cell (8). 
In the current context of the COVID-19 pandemic, vaccination is an effective measure to restrict widespread viral infection, and may also prevent future outbreaks. The vaccines currently used against SARS-CoV-2 primarily target either the $\mathrm{S}$ protein or its receptor-binding domain (RBD) (1). The ongoing vaccine development trial involves classical molecular strategies that are based upon inactivated, modified live or attenuated virus, single peptides or viral vectors (1). Although such vaccines have been used for long periods against several viral diseases, they still present multiple issues, such as the risk of reversion to virulence, inability to provide long-lasting protection and limited protective immunity (9). Therefore, to overcome the aforementioned drawbacks of existing vaccines, an alternative strategy is required to design vaccines that are safer, exhibit effective antigen presentation and can impart long-term immunity.

\section{Extracellular vesicles (EVs) and their significance}

EVs are lipid bilayer membrane vesicles derived from endosomes, which can be produced by all types of cell, including prokaryotic or eukaryotic and healthy or malignant cells (10). Per the guidelines stated by the International Society of Extracellular Vesicles (10), EVs can be categorized into three types: Microvesicles, apoptotic bodies and exosomes. They are categorized based on size, biogenesis pathway and content. Exosomes are heterogeneous membrane-bound vesicles $30-150 \mathrm{~nm}$ in size (10). Exosomes were previously believed to function in the disposal of unwanted materials from the cell; however, later studies identified a key role in intercellular signaling and the pathogenesis of cancer and infectious disease $(11,12)$. Exosomes are unique from other EVs in that they are released from multi-vesicular bodies (late endosomes) via exocytosis. Once released from the parent cell, they fuse with the plasma membrane of target cells and deliver packaged cargo into the parent cell cytosol (12). The packaged cargo constitutes nucleic acids, lipids and proteins involved in multiple functions, such as the surface display of protein (major histocompatibility complex molecule), epigenetic modification and antigen transfer to dendritic cells for cross-presentation to T cells (13). Among these lipids, exosomes usually carry ceramides, sphingolipids, phosphoglycerides and cholesterol, which serve essential roles in cargo sorting and internalization (14).

Exosomes (Fig. 2) can be recognized by the type of proteins they contain; these include GTPase, which are membrane transport proteins; CD63, CD81, CD82 and CD9, which are molecular scaffolds; endosomal sorting complex required for transport (ESCRT), which is a biogenesis-associated protein; and heat shock protein (HSP)60, HSP90 and HSP70 (15). Healthy cells release exosomes under normal physiological conditions to mediate intercellular communication against growth or stress response (16). In addition, exosomes are released by various types of cell, including cancer, mesenchymal stem and immune cells $(17,18)$. They are also present in a variety of body fluids, such as plasma, urine, semen, saliva and breast milk $(19,20)$.

Exosomes derived from apoptotic cells, also known as apoptotic exosomes (ApoExos), are newly discovered types of EVs formed in a caspase-dependent pathway and secreted during apoptosis. Unlike exosomes, ApoExos are produced via sphingosine-1-phosphate receptor (S1P) signaling independently of ESCRT (21). ApoExos share similar characteristics with exosomes in terms of size, protein expression and role in intercellular communication (21) and exhibit exosome-specific markers such as HSP70, lysosomal-associated membrane protein 1 and CD63. ApoExos consist of distinctive marker proteins (S1P receptors 1 and 3 ) that induce inflammation in mouse macrophages (22). ApoExos have two primary functions: Apoptotic cell clearance and cell signaling. Similar to exosomes, the role of ApoExos in cell communication involves immune modulation, such as antigen presentation during autoimmunity.

\section{Exosome-based vaccines}

Exosome-based vaccines may be considered as the future of therapeutics owing to their involvement in disease progression and their role in inhibiting viral infection and triggering host immune response (Fig. 3). There is similarity between viruses and exosomes in terms of size, biochemical composition, mechanisms of biomolecule transfer, facilitation of entry into host cells and biogenesis and multiplication of viruses in host cells. Human immunodeficiency virus-1 is a notable example, wherein the virus hijacks EV biogenesis to enhance its spread into the host body by exploiting the ESCRT pathway $(23,24)$. Furthermore, changes in EV cargo during viral infection, such as the transfer of viral particles into uninfected cells and immune response modulation, have led researchers to characterize EVs and investigate their therapeutic potential (such as a drug delivery system) or use in antigen presentation for safe vaccine design (25).

To design an efficacious vaccine, multiple criteria should be considered (26). Given that EVs efficiently carry cargo, thus acting as natural delivery vehicles, they constitute a specific and efficient delivery system in terms of antigen presentation (27). Moreover, characteristics of EVs, such as high vascular permeability, stability, solubility and bio-distribution, make them ideal candidates for vaccines (28). An appropriate approach to develop a safe vaccine is important. Numerous in vivo studies have evaluated the toxicity and immunogenicity of EVs $(28,29)$. In one study, CD81 $/ \mathrm{CD}^{+} / \mathrm{CD} 63^{+} \mathrm{EVs}$ derived from human embryonic kidney Expi293F cells caused no change in mRNA expression levels of HepG2 cells; moreover, no hepatotoxicity or inflammation induction was noted in BALB/c mice (29). In another study, the administration of $\mathrm{CD}{ }^{+} / \mathrm{TSG} 101^{+}$EVs from human embryonic kidney $293 \mathrm{~T}$ cells did not result in toxicity or immune response in mice, affirming the safety of EVs in an in vivo model (30).

The key features of EV-based vaccines, including their ability to induce poor immunogenicity, mean EVs can be safely and efficiently used in vaccine development. The ability of EVs to preserve naïve antigen conformation and access to all organs via bodily fluids give an added advantage compared with other delivery agents, such as lipid-based nanoparticles (LNPs) or viral vectors (31). Therefore, engineered EVs fulfill the criteria for an efficacious vaccine due to their efficient antigen-presenting system, and high biosafety.

\section{Prospects of exosome-based COVID-19 vaccines}

With the increasing global prevalence of COVID-19, the development of an effective vaccine is imperative to contain the pandemic. No specific antiviral treatment is currently 


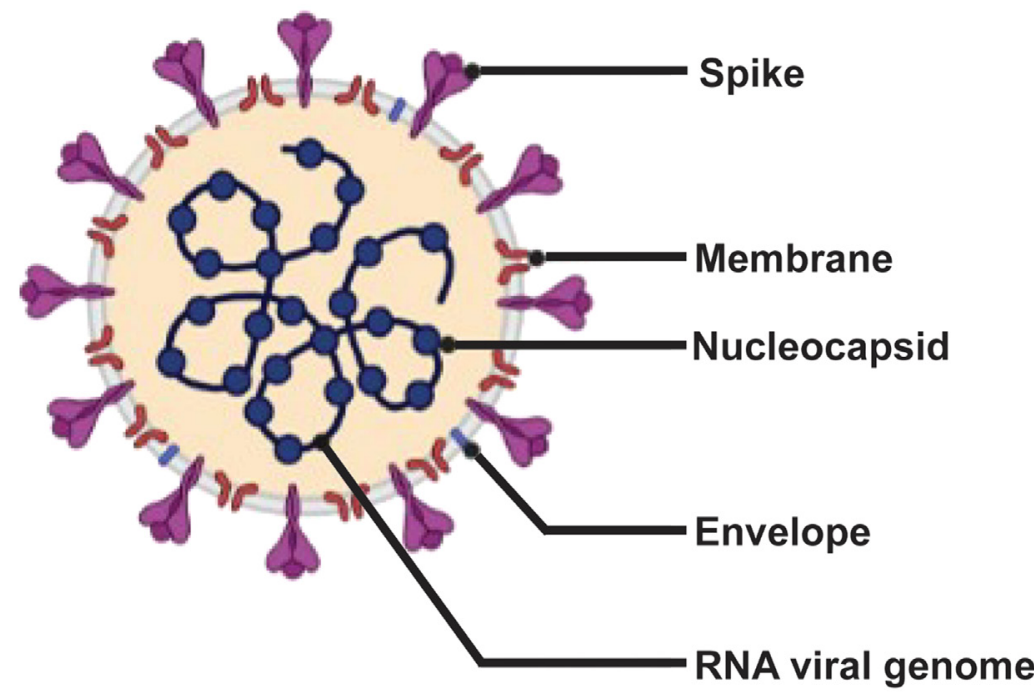

Figure 1. Schematic diagram of severe acute respiratory syndrome coronavirus 2 . The four structural proteins (spike, envelope, membrane and nucleocapside) are shown; the spike glycoprotein mediates host cell binding.

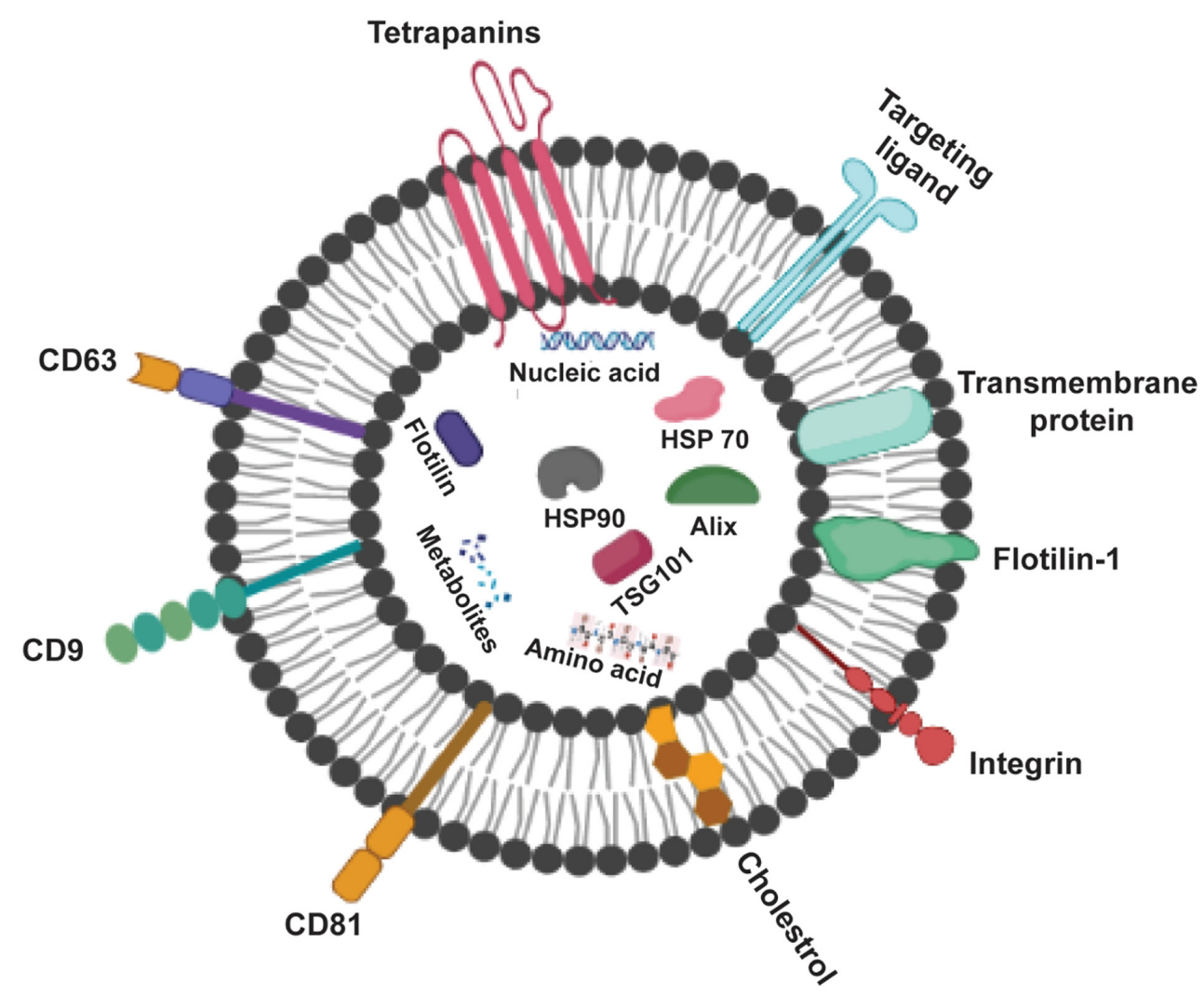

Figure 2. Structure and hallmarks of exosomes. Exosomes are surrounded by a phospholipid bilayer and consist of proteins including CD63, an exosomal marker, and tetraspanins for cell targeting. HSP, heat shock protein; TSG101, tumor susceptibility 101.

available for public use. However, since the SARS-CoV-2 genomic sequence was identified, $>100$ vaccine studies have been performed, $\sim 50$ of which have reached human experimentation and a number of vaccines are currently being administered to certain sections of the population (ourworldindata.org/covid-vaccinations). Vaccines approved by medical regulators for use in the US, Europe and the UK include BNT162b2 and mRNA-1273. ChAdOx1 nCoV-19, a vaccine produced by AstraZeneca, has been approved by the
UK authorities. Additionally, BNT162b2, a Pfizer-BioNTech COVID-19 vaccine, has recently received US Food and Drug Administration approval for individuals aged $\geq 16$ years.

Currently available SARS-CoV-2 vaccines are based on the classical approach of viral vectors, particularly adenoviruses. Although adenovirus-based vaccines are well-characterized, they are limited by pre-existing immunity of the virus vector employed in the vaccine design, which may restrict the immune response against COVID-19 antigens, thereby decreasing their efficacy (9). 
Table I. Advantages and disadvantages of vaccine approaches.

\begin{tabular}{|c|c|c|}
\hline Vaccine type & Advantages & Disadvantages \\
\hline Adenoviral vector & $\begin{array}{l}\text { - Direct production of antigen } \\
\text { in the cell of interest } \\
\text { - Multiple epitopes can be included } \\
\text { - Scalable production globally } \\
\text { - More immunogenic than other types } \\
\text { of viral vector }\end{array}$ & $\begin{array}{l}\text { - Pre-existing anti-adenovirus immunity } \\
\text { and potential adverse events, } \\
\text { such as dangerous blood clots } \\
\text { - Lack of strong, long-lasting immunity } \\
\text { after single dose } \\
\text { - Vaccine-induced thrombotic thrombocytopenia }\end{array}$ \\
\hline DNA & $\begin{array}{l}\text { - Stimulation of both humoral and } \\
\text { cell-mediated immunity } \\
\text { - Construction of a vector encoding different } \\
\text { antigens in a single vaccine } \\
\text { - Efficient large-scale, low-cost, production } \\
\text { and high storage stability }\end{array}$ & $\begin{array}{l}\text { - Need delivery agent to be translocated } \\
\text { into the nucleus } \\
\text { - Poor immune response } \\
\text { - Only licensed for use in veterinary medicine }\end{array}$ \\
\hline RNA & $\begin{array}{l}\text { - Ease and rapidity of assembling novel mRNA } \\
\text { sequences into existing vaccine formulations } \\
\text { - Non-toxic and non-immunogenic } \\
\text { - Variant-specific boosters not required } \\
\text { - No risk of integration with host cell genome }\end{array}$ & $\begin{array}{l}\text { - Rare, severe anaphylactic reactions } \\
\text { - Long-term immunity issue } \\
\text { - Expensive to manufacture }\end{array}$ \\
\hline $\begin{array}{l}\text { Recombinant } \\
\text { protein }\end{array}$ & $\begin{array}{l}\text { - Easy to produce at large-scale (cost-efficient). } \\
\text { - Can be produced in different } \\
\text { expression systems } \\
\text { - Well-defined composition }\end{array}$ & $\begin{array}{l}\text { - Expression of only fragment of the protein } \\
\text { (not whole protein) } \\
\text { - More prone to be impacted by antigenic drift } \\
\text { - Usually elicits weak immune responses } \\
\text { - Need adjuvant }\end{array}$ \\
\hline $\begin{array}{l}\text { Extracellular } \\
\text { vesicle-based }\end{array}$ & $\begin{array}{l}\text { - Excellent carriers for viral antigens; } \\
\text { present antigens in their native state } \\
\text { - Can self-present antigens (surface major } \\
\text { histocompatibility complex molecules) } \\
\text { - Can generate protective immune responses } \\
\text { - Can pass through the blood-brain barrier }\end{array}$ & $\begin{array}{l}\text { - Production and scalability are difficult } \\
\text { - Characterization of immune responses } \\
\text { for each disease needs further research }\end{array}$ \\
\hline
\end{tabular}

Another point of concern is the risk of re-infection with emerging viruses in the community due to lack of long-lasting immunity. Thus, viral infection may become endemic (similar to the influenza virus endemic), necessitating yearly vaccination programs. Multiple immunizations with such viral vectors, if not effective, could lead to more complicated form of the disease, such as antibody-dependent enhancement (ADE), increasing the disease burden (32). ADE, a theoretical exaggeration of disease severity, usually occurs in an infected individual during viral infection or following vaccination against viral-based antigens when an antibody against a pathogen amplifies the infection instead of protecting an individual against it. Such adverse effects may pose more danger to an individual than the original disease. Notably, certain recipients of the AstraZeneca COVID-19 vaccine, which has received approval by the UK authorities, exhibited a rare blood-clotting disorder; hence, the safety of these vaccines is questionable (33).

EV-based vaccines constitute an innovative approach for an efficient virus-free, human-derived vaccine design; this eliminates the aforementioned virus vector-based vaccine drawbacks associated with pre-exiting immunity. Due to this advantage of EVs over virus-based vectors, a number of biotechnology companies are focusing on vaccine development using EVs as a platform against SARS-CoV-2. Capricor Therapeutics, for example, developed two distinct SARS-CoV-2 vaccines using an EV-based platform. First, they developed an EV-display vaccine comprising 293T cells transfected with vectors expressing the four structural SARS-CoV-2 proteins (S, E, M and N proteins). Secondly, they developed an exosome-based mRNA vaccine encoding the $\mathrm{N}$ and $\mathrm{S}$ proteins of immunogenic SARS-CoV-2. Moreover, they recently reported that mRNA-loaded exosome vaccines elicit long-lasting cellular and humoral responses to both the $\mathrm{N}$ and $\mathrm{S}$ proteins and result in fewer adverse effects than currently available COVID-19 vaccines (34). Similarly, Polak et al (35) recently reported induction of neutralizing antibody (NAb) and cellular response by EV-based vaccines enclosing viral envelope proteins in mice, thereby eliminating the need for adjuvants. Furthermore, Codiak BioSciences has reported the safety and tolerability profile of EV-derived vaccines displaying the anti-tumor cytokine IL-12 from 293T cells in a Phase 1 trial (36). Table I shows the comparative advantages and disadvantages of currently available and exosome-based vaccines. 


\section{Immunological perspective of present and future vac- cine development strategies}

With the global spread of emerging COVID-19 variants (37), it is critical to develop a protective vaccine that is effective against multiple strains of SARS-CoV-2. Moreover, to develop an effective strategy, the mechanism of the natural immune response against SARS-CoV-2 needs to be thoroughly understood and targeted.

Ongoing trials for SARS-CoV-2 vaccine construction are based on the principle of eliciting NAbs against the $\mathrm{S}$ protein, thereby interfering with viral-receptor binding $(38,39)$. To date, research associated with COVID-19 vaccine development has focused primarily on antibody titers and the ability of antibodies to neutralize viral particles (40). A number of studies have focused on inducing NAb production against the $\mathrm{S}$ protein; this overlooks cell-mediated immunity, a key aspect of adaptive immunity $(39,41)$.

Both viruses and vaccines induce virus-specific $\mathrm{T}$ cell responses, in addition to antibody responses (42). The potential to elicit virus-specific $\mathrm{T}$ cell response should be exploited for enhanced immune protection. A recent study reported long-lasting memory $\mathrm{T}$ cell immunity specific to the original SARS-CoV up to 17 years after initial infection; these SARS-CoV-specific T cells were almost exclusively directed against the N protein (43). Studies on SARS-CoV, SARS-CoV-2 and MERS-CoV have confirmed the induction of both $\mathrm{CD}^{+}$ and $\mathrm{CD}^{+} \mathrm{T}$ cell responses against the $\mathrm{S}$ protein $(44,45)$. The $\mathrm{S}$ gene of SARS-CoV-2 shares a $76 \%$ amino acid similarity with the $\mathrm{S}$ gene of SARS-CoV $(44,46)$ and is more prone to mutation $(47,48)$. By contrast, the $\mathrm{N}$ gene is more stable and conserved, with $90 \%$ amino acid homology and fewer mutations over time (49-52). The abundance of the $\mathrm{N}$ protein, along with its high immunogenicity, makes it a key target for both antibody- and cell-mediated immunity to elicit a strong adaptive immune response (52). A previous study detected IgG antibodies against the $\mathrm{N}$ protein in sera of patients with SARS (53); the presence of SARS-specific T cell proliferation and cytotoxic activity have also been detected, indicating that the $\mathrm{N}$ protein is the primary antigen for $\mathrm{T}$ cell-mediated immunity $(54,55)$.

Grifoni et al (44) demonstrated the presence of SARS-CoV-2 $\mathrm{CD}^{+} \mathrm{T}$ cells against the $\mathrm{S}$ and $\mathrm{M}$ proteins in COVID-19 convalescent patients. Ferretti et al (56) validated the presence of maximal common epitopes on ORF1ab, N, M and ORF3ab protein, but very few on the S protein; only one epitope was found in the RBD of the $S$ protein. These results provide better understanding of the $\mathrm{CD}^{+} \mathrm{T}$ cell response in patients with COVID-19, as well as a route for designing and developing next-generation vaccines (56). A recently published study by Zollner et al (57) reported that the $\mathrm{N}$ protein is a potent $\mathrm{T}$ cell inducer. These results indicate the significance of $\mathrm{CD}^{+} \mathrm{T}$ cell response in SARS-CoV-2 infection, which may be another vaccine target (57).

Contrary to the $\mathrm{S}$ and $\mathrm{N}$ proteins of SARS-CoV-2, the $\mathrm{M}$ and $\mathrm{E}$ proteins do not possess strong immunogenicity to trigger antibody-mediated responses (58). However, the sequence identity of both the $\mathrm{M}$ and $\mathrm{E}$ proteins among SARS-CoV, MERS-CoV, and SARS-CoV-2 is greater than that of the $\mathrm{S}$ protein, suggesting them as a potential target to induce
T cell-mediated immune response. Furthermore, a previous study on SARS-CoV and MERS-CoV immunity reported that several $\mathrm{T}$ cell epitopes were found in the $\mathrm{M}$ and $\mathrm{E}$ proteins (45). These findings suggest that including all these proteins as antigens for the development of vaccines may improve protection against SARS-CoV-2 infection by imparting both T cell- and antibody-based protection; moreover, this may protect an individual against SARS-CoV variants.

$\mathrm{T}$ cell-mediated immunity may resolve the challenges associated with providing long-term immunity against SARS-CoV-2 by existing vaccines, which target only the $\mathrm{S}$ protein to produce Nabs (39-41). As previously reported, individuals who recover from SARS-CoV infection show virus-specific memory $\mathrm{CD}^{+} \mathrm{T}$ cells that last for 6-11 years, whereas memory $\mathrm{B}$ cells and antiviral antibodies are not detected for such periods of time in these individual (59). Similarly, antibody response decreases within 3 months in patients with COVID-19 (60). In addition, certain vaccines are ineffective against the delta variant, which is more infectious and highly transmissible that other COVID-19 variants (61). Therefore, vaccines solely based on NAbs cannot provide long-term immunity against COVID-19; furthermore, the relevance of cell-mediated immunity should be acknowledged and considered for vaccine development amid the ongoing pandemic.

\section{Safety aspect of $293 \mathrm{~T}$ cells for exosome-based vaccine production}

293T cells are utilized for production of EV vaccines because of their high transfection efficiency and rapid growth (62). $293 \mathrm{~T}$ cells are used in the intermediate and final production of exosome-based vaccines, as well as multiple types of COVID-19 vaccine. For example, the Oxford-AstraZeneca adenovirus-based COVID-19 vaccine is derived from $293 \mathrm{~T}$ cells (63). Moreover exosome-based vaccines developed by Capricor Therapeutics, Inc. are made of 293T cells transfected with vectors that express the four structural SARS-CoV-2 proteins. However, due to difficulties in large-scale production of purified exosomes, the company has been unable to market this vaccine (36).

CKV21, an exosome-based virus like particle vaccine, is manufactured by Korean biotechnology company CK-Exogene, Inc. This vaccine uses $\mathrm{S}, \mathrm{M}, \mathrm{E}$ and $\mathrm{N}$ protein genes cloned into $293 \mathrm{~T}$ cells using a viral vector. Following mass culture of these cells, exosomes containing S, M, E and N proteins are produced. Cyclohexamide is added prior to centrifugation; this promotes exosome secretion after $48 \mathrm{~h}$ (Fig. 4). In addition, due to the nature of exosomes, they are easily absorbed into human cells without a special delivery medium (64). As a result, this vaccine is non-adjuvanted, virus-free and comprises all four structural proteins (with the $\mathrm{N}$ protein being minimal); thus, the vaccine aims to induce strong immunogenicity against SARS-CoV-2 mutant variants.

Unlike other companies, such as Capricor Therapeutics and Codiak Biosciences that have failed to produce exosomes on a mass commercial scale, CK-Exogene, Inc. manufactures exosomes on a large scale. Patented technology is able to produce a quantity of exosomes $\geq 1,000$ times higher than that produced by existing technology. Fig. 4 depicts the 


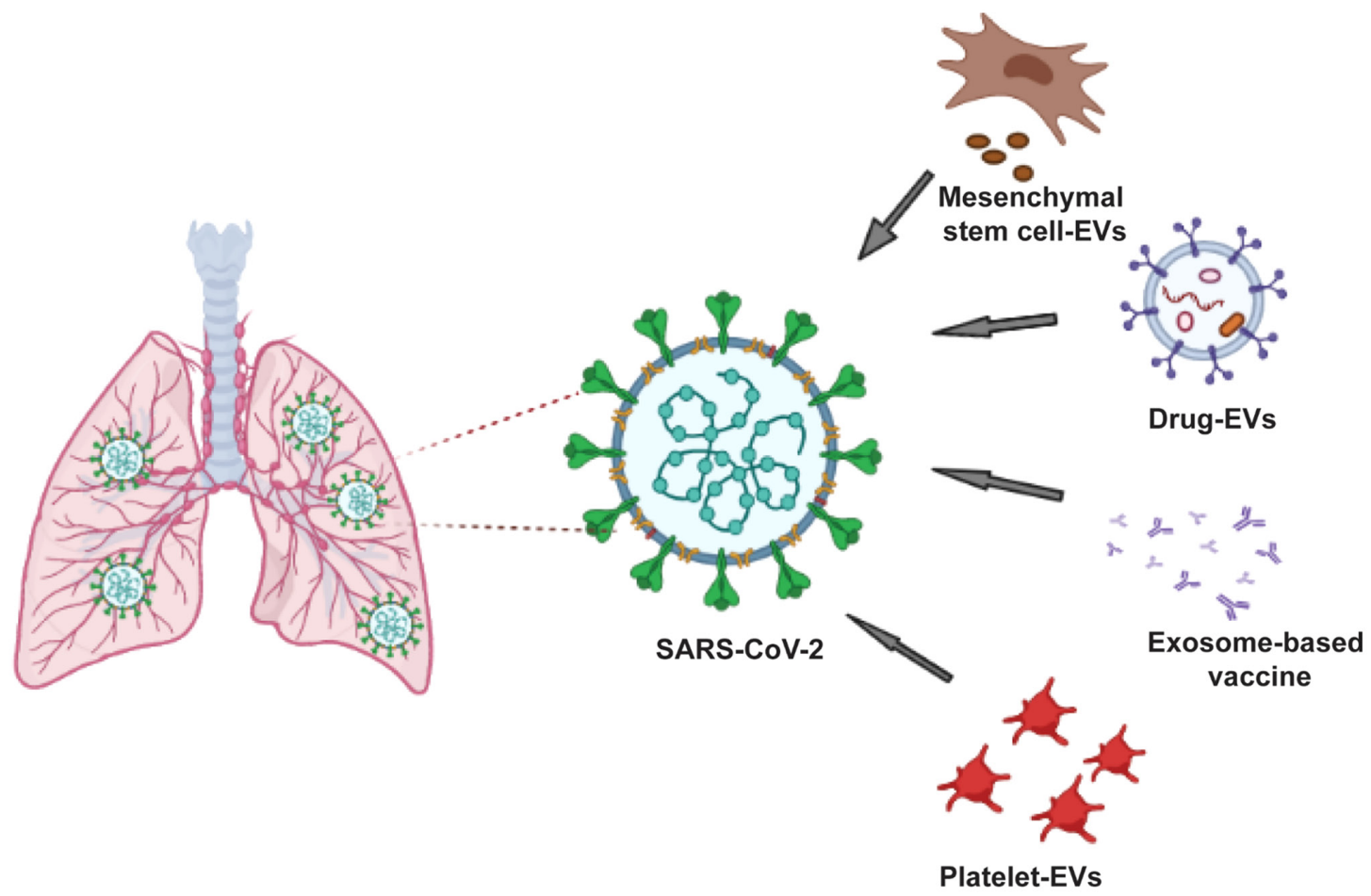

Figure 3. Approaches to exosome-based vaccine in the management of coronavirus disease 2019. EVs, extracellular vesicles; SARS-CoV-2, severe acute respiratory syndrome coronavirus 2 .

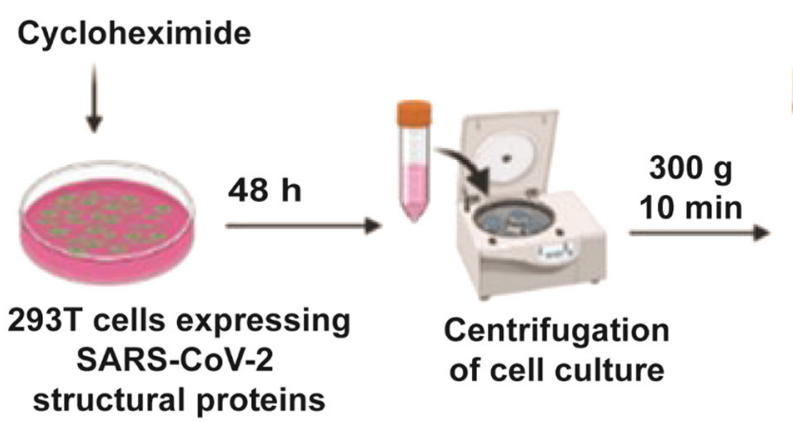

\section{Supernatant with EVs}

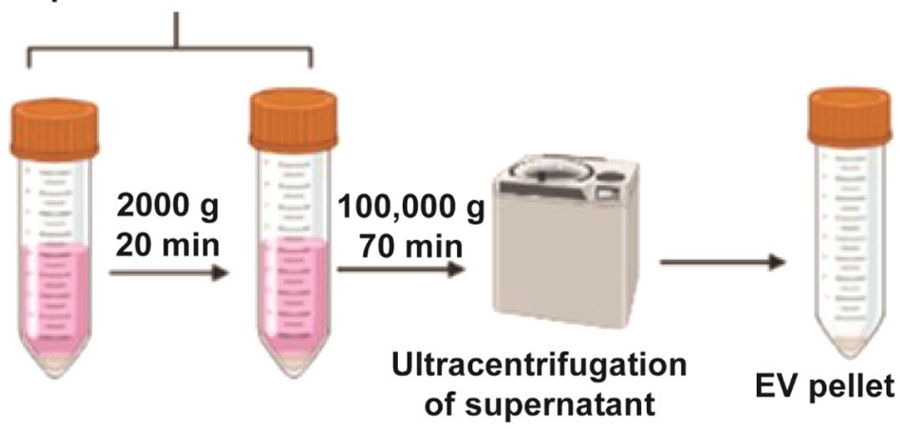

Figure 4. Diagrammatic representation of ultracentrifugation-based exosome isolation (Korean patent application no. 10-2020-0062365) for the mass production of $293 \mathrm{~T}$ cell-derived apoptotic exosomes. SARS-CoV-2, severe acute respiratory syndrome coronavirus 2; EV, extracellular vesicle.

purification strategy for the mass production of highly purified and concentrated exosomes (Korean patent application no. 10-2020-0062365). Production of apoptotic exosomes was induced using Golgi bodies; such exosomes are more concentrated and purified than normal exosomes. The CKV21 vaccine is awaiting approval from the Ministry of Food and Drug Safety (Korean Food and Drug Administration), prior to commercialization.

In exosome-based vaccine, it is important to examine and characterize the safety of EV-producing cells that are employed for therapeutic purposes to avoid any potential side effects. Numerous studies have reported that 293T cells are a safe source for EV production in therapeutics because their cargo does not exhibit disease or tumor marker $(62,63)$. To the best of our knowledge, however, few studies have highlighted other aspects of $293 \mathrm{~T}$ cells $(63,65)$.
Regarding the safety of use of 293T cells, SV40 T antigen was found to trigger both in vitro and in vivo transformation of human and rat cells; notably, SV40-transformed 293T cells reportedly cause tumors when administered to nude mice (66). Therefore, EVs derived from $293 \mathrm{~T}$ cells may pose a safety concern due to the presence of SV40 T antigens (66).

Shen et al (67) revealed a significant effect of the passage number of 293T cells on tumorigenicity in nude mice; tumor induction was observed when the cell passage exceeded 65 within 2 weeks. By contrast, no tumor production was found after injecting mice with 293T cells with a low passage number $(<52)$ under identical circumstances. These findings were validated using PCR, isoenzyme and histological analysis in nude mice. Therefore, 293T cells with a low passage number $(<52)$ may be safely used in EV production, whereas those with a high passage number ( $>65)$ may pose a safety concern, 
especially when used for therapeutic purposes such as gene therapy or vaccine production.

\section{Conclusions}

Immunologically, a vaccine that targets the mutation-prone $\mathrm{S}$ protein as well as the more stable and conserved $\mathrm{N}, \mathrm{M}$, and $\mathrm{E}$ proteins is required to surmount the immune escape characteristics exhibited by SARS-CoV-2 variants (37). The use of exosome-based vaccines displaying SARS-CoV-2 structural proteins is a novel approach to overcome the shortcomings of existing vaccines and contain escalating cases of COVID-19 (62). Exosome-based vaccines comprising all four-target antigens (S, M, E and N proteins) induce strong $\mathrm{NAb}$ and $\mathrm{T}$ cell responses, thereby conferring prolonged immunity with no risk of reversion of vaccination-induced virulence and pre-existing immunity. Moreover, incorporating these immunogens with an efficient delivery vehicle, such as exosomes, which are virus-free and exhibit lower immunogenicity and higher absorption rate than exiting vehicles such as LNPs or adenoviruses, would fulfill the requirements of an ideal vaccine that eliminates the need for booster doses (63). These advantages of exosome-based vaccines over conventional vaccines fit the requirement of a vaccine targeting SARS-CoV-2 and emerging SARS-CoV-2 variants.

\section{Acknowledgements}

Not applicable.

\section{Funding}

No funding was received.

\section{Availability of data and materials}

Data sharing not applicable to this article, as no datasets were generated or analyzed during the current study.

\section{Authors' contributions}

KHY, NT, BJK, JOL, YNJ, YJC and JK made substantial contributions to study conception and design, data acquisition and data analysis and interpretation and wrote and critically revised the manuscript for important intellectual content. Data authentication is not applicable. All authors read and approved the final version of the manuscript.

\section{Ethics approval and consent to participate}

Not applicable.

\section{Patient consent for publication}

Not applicable.

\section{Competing interests}

The purification strategy for the mass production of highly purified and concentrated exosomes is subject to Korean patent application no. 10-2020-0062365, associated with CK-Exogene, Inc. JK and NT are employees of CK-Exogene, Inc. The other authors (KHY, BJK, JOL, YNJ and YJC) are not associated with CK-Exogene, Inc. and declare that they have no competing interests.

\section{References}

1. Cascella M, Rajnik M, Aleem A, Dulebohn S and Di Napoli R: Features, Evaluation, and Treatment of Coronavirus (COVID-19). StatPearls, 2021.

2. Zhou P, Yang XL, Wang XG, Hu B, Zhang L, Zhang W, Si HR, Zhu Y, Li B, Huang CL, et al: A pneumonia outbreak associated with a new coronavirus of probable bat origin. Nature 579: 270-273, 2020.

3. Mousavizadeh L and Ghasemi S: Genotype and phenotype of COVID-19: Their roles in pathogenesis. J Microbiol Immunol Infect 54: 159-163, 2021.

4. Wrapp D, Wang N, Corbett KS, Goldsmith JA, Hsieh CL, Abiona O, Graham BS and McLellan JS: Cryo-EM structure of the 2019-nCoV spike in the prefusion conformation. Science 367: 1260-1263, 2020.

5. Walls AC, Park YJ, Tortorici MA, Wall A, McGuire AT and Veesler D: Structure, function, and antigenicity of the SARS-CoV-2 spike glycoprotein. Cell 181: 281-292.e6, 2020.

6. Jaimes JA, André NM, Chappie JS, Millet JK and Whittaker GR: Phylogenetic analysis and structural modeling of SARS-CoV-2 spike protein reveals an evolutionary distinct and proteolytically sensitive activation loop. J Mol Biol 432: 3309-3325, 2020.

7. Kang S, Yang M, Hong Z, Zhang L, Huang Z, Chen X, He S, Zhou Z, Zhou Z, Chen Q, et al: Crystal structure of SARS-CoV-2 nucleocapsid protein RNA binding domain reveals potential unique drug targeting sites. Acta Pharm Sin B 10: 1228-1238, 2020.

8. Hoffmann M, Kleine-Weber H, Schroeder S, Krüger N, Herrler T, Erichsen S, Schiergens TS, Herrler G, Wu NH, Nitsche A, et al: SARS-CoV-2 cell entry depends on ACE2 and TMPRSS2 and is blocked by a clinically proven protease inhibitor. Cell 181: 271-280.e8, 2020.

9. Ghaebi M, Osali A, Valizadeh H, Roshangar L and Ahmadi M: Vaccine development and therapeutic design for 2019-nCoV/ SARS-CoV-2: Challenges and chances. J Cell Physiol 235: 9098-9109, 2020.

10. Théry C, Witwer KW, Aikawa E, Alcaraz MJ, Anderson JD, Andriantsitohaina R, Antoniou A, Arab T, Archer F, AtkinSmith GK, et al: Minimal information for studies of extracellular vesicles 2018 (MISEV2018): A position statement of the International Society for Extracellular Vesicles and update of the MISEV2014 guidelines. J Extracell Vesicles 7: 1535750, 2018.

11. Kowal J, Tkach M and Théry C: Biogenesis and secretion of exosomes. Curr Opin Cell Biol 29: 116-125, 2014.

12. Minciacchi VR, Freeman MR and Di Vizio D: Extracellular vesicles in cancer: Exosomes, microvesicles and the emerging role of large oncosomes. Semin Cell Dev Biol 40: 41-51, 2015.

13. Choi DS, Kim DK, Kim YK and Gho YS: Proteomics, transcriptomics and lipidomics of exosomes and ectosomes. Proteomics 13: 1554-1571, 2013.

14. Record M, Carayon K, Poirot M and Silvente-Poirot S: Exosomes as new vesicular lipid transporters involved in cell-cell communication and various pathophysiologies. Biochim Biophys Acta 1841: 108-120, 2014.

15. Zhang Y, Yu M and Tian W: Physiological and pathological impact of exosomes of adipose tissue. Cell Prolif 49: 3-13, 2016.

16. Yarana $\mathrm{C}$ and St Clair DK: Chemotherapy-induced tissue injury: An insight into the role of extracellular vesicles-mediated oxidative stress responses. Antioxidants 6: 75, 2017.

17. Zheng H, Zhan Y, Liu S, Lu J, Luo J, Feng J and Fan S: The roles of tumor-derived exosomes in non-small cell lung cancer and their clinical implications. J Exp Clin Cancer Res 37: 226, 2018.

18. Yu B, Zhang X and Li X: Exosomes derived from mesenchymal stem cells. Int J Mol Sci 15: 4142-4157, 2014

19. Caby MP, Lankar D, Vincendeau-Scherrer C, Raposo G and Bonnerot C: Exosomal-like vesicles are present in human blood plasma. Int Immunol 17: 879-887, 2005.

20. Zlotogorski-Hurvitz A, Dayan D, Chaushu G, Korvala J, Salo T, Sormunen R and Vered M: Human saliva-derived exosomes: Comparing methods of isolation. J Histochem Cytochem 63: 181-189, 2015. 
21. Park SJ,Kim JM,Kim J,Hur J,Park S,Kim K,Shin HJ and Chwae YJ: Molecular mechanisms of biogenesis of apoptotic exosome-like vesicles and their roles as damage-associated molecular patterns. Proc Natl Acad Sci USA 115: E11721-E11730, 2018.

22. Weichand B, Weis N, Weigert A, Grossmann N, Levkau B and Brüne B: Apoptotic cells enhance sphingosine-1-phosphate receptor 1 dependent macrophage migration. Eur J Immunol 43 3306-3313, 2013.

23. Lorizate M, Sachsenheimer T, Glass B, Habermann A, Gerl MJ, Kräusslich HG and Brügger B: Comparative lipidomics analysis of HIV-1 particles and their producer cell membrane in different cell lines. Cell Microbiol 15: 292-304, 2013.

24. Lorizate $\mathrm{M}$ and Kräusslich HG: Role of lipids in virus replication. Cold Spring Harb Perspect Biol 3: a004820, 2011.

25. Dogrammatzis $\mathrm{C}$, Waisner $\mathrm{H}$ and Kalamvoki M: Cloaked viruses and viral factors in cutting edge exosome-based therapies. Front Cell Dev Biol 8: 376, 2020.

26. Nainu F, Abidin RS, Bahar MA, Frediansyah A, Emran TB, Rabaan AA, Dhama K, Harapan H; SARS-CoV-2 reinfection and implications for vaccine development. Hum Vaccin Immunother 16: 3061-3073, 2020

27. Zhao X, Wu D, Ma X, Wang J, Hou W and Zhang W: Exosomes as drug carriers for cancer therapy and challenges regarding exosome uptake. Biomed Pharmacother 128: 110237, 2020.

28. Sun D, Zhuang X, Xiang X, Liu Y, Zhang S, Liu C, Barnes S, Grizzle W, Miller D and Zhang HG: A novel nanoparticle drug delivery system: The anti-inflammatory activity of curcumin is enhanced when encapsulated in exosomes. Mol Ther 18: $1606-1614,2010$

29. Saleh AF, Lázaro-Ibáñez E, Forsgard MA, Shatnyeva O Osteikoetxea X, Karlsson F, Heath N, Ingelsten M, Rose J, Harris J, et al: Extracellular vesicles induce minimal hepatotoxicity and immunogenicity. Nanoscale 11: 6990-7001, 2019.

30. Zhu X, Badawi M, Pomeroy S, Sutaria DS, Xie Z, Baek A, Jiang J, Elgamal OA, Mo X, Perle K, et al: Comprehensive toxicity and immunogenicity studies reveal minimal effects in mice following sustained dosing of extracellular vesicles derived from HEK293T cells. J Extracell Vesicles 6: 1324730, 2017.

31. Walker S, Busatto S, Pham A, Tian M, Suh A, Carson K, Quintero A, Lafrence M, Malik H, Santana MX, et al: Extracellular vesicle-based drug delivery systems for cancer treatment. Theranostics 9: 8001-8017, 2019.

32. Arvin AM, Fink K, Schmid MA, Cathcart A, Spreafico R, Havenar-Daughton C, Lanzavecchia A, Corti D and Virgin HW: A perspective on potential antibody-dependent enhancement of SARS-CoV-2. Nature 584: 353-363, 2020.

33. Greinacher A, Thiele T, Warkentin TE, Weisser K, Kyrle PA, Eichinger S; Thrombotic thrombocytopenia after ChAdOx1 nCov-19 vaccination. N Engl J Med 384: 2092-2101, 2021.

34. Tsai SJ, Guo C, Atai NA and Gould SJ: Exosome-mediated mRNA delivery for SARS-CoV-2 vaccination. bioRxiv: Nov 6 , 2021 (Epub ahead of print). doi: 10.1101/2020.11.06.371419.

35. Polak K, Greze N, Lachat M, Merle D, Chiumento S, Bertrand-Gaday C, Trentin B and Mamoun R: Extracellular vesicle-based vaccine platform displaying native viral envelope proteins elicits a robust anti-SARS-CoV-2 response in mice. bioRxiv: Oct 28, 2020 (Epub ahead of print). doi: org/10.1101/2 020.10 .28 .357137

36. Lewis ND, Sia CL, Kirwin K, Haupt S, Mahimkar G, Zi T, Xu K, Dooley K, Jang SC, Choi B, et al: Exosome surface display of IL12 results in tumor-retained pharmacology with superior potency and limited systemic exposure compared with recombinant IL12. Mol Cancer Ther 20: 523-534, 2021.

37. Garcia-Beltran WF, Lam EC, St Denis K, Nitido AD, Garcia ZH, Hauser BM, Feldman J, Pavlovic MN, Gregory DJ, Poznansky MC, et al; Multiple SARS-CoV-2 variants escape neutralization by vaccine-induced humoral immunity. Cell 184: 2372-2383, 2021

38. Vabret N, Britton GJ, Gruber C, Hegde S, Kim J, Kuksin M, Levantovsky R, Malle L, Moreira A, Park MD, et al; Sinai Immunology Review Project: Immunology of COVID-19: current state of the science. Immunity 52: 910-941, 2020.

39. Niu L, Wittrock KN, Clabaugh GC, Srivastava V and Cho MW; A structural landscape of neutralizing sntibodies sgainst SARS-CoV-2 receptor binding fomain. Front Immunol 12 . 647934, 2021.

40. Garcia-Beltran WF, Lam EC, Astudillo MG, Yang D, Miller TE, Feldman J, Hauser BM, Caradonna TM, Clayton KL Nitido AD, et al; COVID-19-neutralizing antibodies predict disease severity and survival. Cell 184: 476-488, 2021.
41. Prompetchara E, Ketloy C, Tharakhet K, Kaewpang P, Buranapraditkun S, Techawiwattanaboon T, Sathean-Anan-KunS, Pitakpolrat P, Watcharaplueksadee S, Phumiamorn S, et al; DNA vaccine candidate encoding SARS-CoV-2 spike proteins elicited potent humoral and Th1 cell-mediated immune responses in mice. PLoS One 16: e0248007, 2021.

42. Khoury DS, Cromer D, Reynaldi A, Schlub TE, Wheatley AK, Juno JA, Subbarao K, Kent SJ, Triccas JA and Davenport MP: Neutralizing antibody levels are highly predictive of immune protection from symptomatic SARS-CoV-2 infection. Nat Med 27: 1205-1211, 2021.

43. Le Bert N, Tan AT, Kunasegaran K, Tham CY, Hafezi M, Chia A, Chng MH, Lin M, Tan N, Linster M, et al: SARS-CoV-2specific T cell immunity in cases of COVID-19 and SARS, and uninfected controls. Nature 584: 457-462, 2020.

44. Grifoni A, Weiskopf D, Ramirez SI, Mateus J, Dan JM, Moderbacher CR, Rawlings SA, Sutherland A, Premkumar L, Jadi RS, et al: Targets of T cell responses to SARS-CoV-2 coronavirus in humans with COVID-19 disease and unexposed individuals. Cell 181: 1489-1501.e15, 2020.

45. Liu WJ, Zhao M, Liu K, Xu K, Wong G, Tan W and Gao GF: T-cell immunity of SARS-CoV: Implications for vaccine development against MERS-CoV. Antiviral Res 137: 82-92, 2017.

46. Grifoni A, Sidney J, Zhang Y, Scheuermann RH, Peters B and Sette A: A sequence homology and bioinformatic approach can predict candidate targets for immune responses to SARS-CoV-2. Cell Host Microbe 27: 671-680.e2, 2020.

47. Yang ZY, Werner HC, Kong WP, Leung K, Traggiai E, Lanzavecchia A and Nabel GJ: Evasion of antibody neutralization in emerging severe acute respiratory syndrome coronaviruses. Proc Natl Acad Sci USA 102: 797-801, 2005.

48. Ruan YJ, Wei CL, Ee AL, Vega VB, Thoreau H, Su ST, Chia JM, Ng P, Chiu KP, Lim L, et al: Comparative full-length genome sequence analysis of 14 SARS coronavirus isolates and common mutations associated with putative origins of infection. Lancet 361: 1779-1785, 2003.

49. Holmes KV and Enjuanes L: Virology. The SARS coronavirus: A postgenomic era. Science 300: 1377-1378, 2003.

50. Rota PA, Oberste MS, Monroe SS, Nix WA, Campagnoli R, Icenogle JP, Peñaranda S, Bankamp B, Maher K, Chen MH, et al: Characterization of a novel coronavirus associated with severe acute respiratory syndrome. Science 300: 1394-1399, 2003.

51. Zhu Y, Liu M, Zhao W, Zhang J, Zhang X, Wang K, Gu C, Wu K, $\mathrm{Li} \mathrm{Y,} \mathrm{Zheng} \mathrm{C,} \mathrm{et} \mathrm{al:} \mathrm{Isolation} \mathrm{of} \mathrm{virus} \mathrm{from} \mathrm{a} \mathrm{SARS} \mathrm{patient} \mathrm{and}$ genome-wide analysis of genetic mutations related to pathogenesis and epidemiology from $47 \mathrm{SARS}-\mathrm{CoV}$ isolates. Virus Genes 30: 93-102, 2005.

52. Cong Y, Ulasli M, Schepers H, Mauthe M, V'kovski P, Kriegenburg F, Thiel V, de Haan CAM and Reggiori F: Nucleocapsid protein recruitment to replication-transcription complexes plays a crucial role in coronaviral life cycle. J Virol 94: e01925-e19, 2020.

53. Leung DT, Tam FC, Ma CH, Chan PK, Cheung JL, Niu H, Tam JS and Lim PL: Antibody response of patients with severe acute respiratory syndrome (SARS) targets the viral nucleocapsid. J Infect Dis 190: 379-386, 2004.

54. Gao W, Tamin A, Soloff A, D'Aiuto L, Nwanegbo E, Robbins PD, Bellini WJ, Barratt-Boyes S and Gambotto A: Effects of a SARS-associated coronavirus vaccine in monkeys. Lancet 362 : 1895-1896, 2003.

55. Okada M, Takemoto Y, Okuno Y, Hashimoto S, Yoshida S, Fukunaga Y, Tanaka T, Kita Y, Kuwayama S and Muraki Y: The development of vaccines against SARS corona virus in mice and SCID-PBL/hu mice. Vaccine 23: 2269-2272, 2005.

56. Ferretti AP, Kula T, Wang Y, Nguyen DMV, Weinheimer A Dunlap GS, Xu Q, Nabilsi N, Perullo CR, Cristofaro AW, et al: Unbiased screens show CD8 ${ }^{+} \mathrm{T}$ cells of COVID-19 patients recognize shared epitopes in SARS-CoV-2 that largely reside outside the spike protein. Immunity 53: 1095-1107.e3, 2020.

57. Zollner A, Watschinger C, Rössler A, Farcet MR, Penner A, Böhm V, Kiechl SJ, Stampfel G, Hintenberger R, Tilg H, et al: $\mathrm{B}$ and $\mathrm{T}$ cell response to SARS-CoV-2 vaccination in health care professionals with and without previous COVID-19. EBioMedicine 70: 103539, 2021

58. Fields BN, Knipe DM and Howley PM: Fields virology 6th edition Chapter 28: 825-858, 2013

59. Ng OW, Chia A, Tan AT, Jadi RS, Leong HN, Bertoletti A and Tan YJ: Memory $T$ cell responses targeting the SARS coronavirus persist up to 11 years post-infection. Vaccine 34 : 2008-2014, 2016 
60. Cao Y, Su B, Guo X, Sun W, Deng Y, Bao L, Zhu Q, Zhang X, Zheng Y, Geng $\mathrm{C}$, et al: Potent neutralizing antibodies against SARS-CoV-2 identified by high-throughput single-cell sequencing of convalescent patients' B cells. Cell 182: 73-84.e16, 2020.

61. Walsh EE, Frenck RW Jr, Falsey AR, Kitchin N, Absalon J, Gurtman A, Lockhart S, Neuzil K, Mulligan MJ, Bailey R, et al: Safety and immunogenicity of two RNA-based Covid-19 vaccine candidates. N Engl J Med 383: 2439-2450, 2020.

62. Kim J, Song Y, Park CH and Cho C: Platform technologies and human cell lines for the production of therapeutic exosomes. Extracell Vesicles Circ Nucleic Acids 2: 3-17, 2021.

63. van Doremalen N, Lambe T, Spencer A, Belij-Rammerstorfer S, Purushotham JN, Port JR, Avanzato VA, Bushmaker T, Flaxman A, Ulaszewska M, et al: ChAdOx1 nCoV-19 vaccine prevents SARS-CoV-2 pneumonia in rhesus macaques. Nature 586: 578-582, 2020.
64. L Song, S Tang, X Han, Z Jiang, L Dong, C Liu, Liang X, Dong J, Qiu C, Wang Y, et al; KIBRA controls exosome secretion via inhibiting the proteasomal degradation of Rab27a. Nat Commun 10: 1639, 2019.

65. Li J, Chen X, Yi J, Liu Y, Li D, Wang J, Hou D, Jiang X, Zhang J, Wang J, et al: Identification and characterization of 293T cell-derived exosomes by profiling the protein, mRNA and MicroRNA components. PLoS One 11: e0163043, 2016.

66. Merten OW, Hebben M and Bovolenta C: Production of lentiviral vectors. Mol Ther Methods Clin Dev 3: 16017, 2016.

67. Shen C, Gu M, Song C, Miao L, Hu L, Liang D and Zheng C: The tumorigenicity diversification in human embryonic kidney 293 cell line cultured in vitro. Biologicals 36: 263-268, 2008.

This work is licensed under a Creative Commons

Attribution-NonCommercial-NoDerivatives 4.0 International (CC BY-NC-ND 4.0) License. 